\title{
Phosphorus Sorption and Redistribution on Soil Solid Phase in a Brazilian Haplorthox Amended with Biosolids
}

\author{
Ricardo de Oliveira Munhoz, Ronaldo Severiano Berton, and Otávio Antonio de Camargo
}

Centro de Solos e Recursos Ambientais, IAC/APTA, Caixa Postal 28, 13012-970 Campinas, SP, Brazil

Correspondence should be addressed to Ronaldo Severiano Berton, berton@iac.sp.gov.br

Received 16 December 2010; Revised 14 April 2011; Accepted 23 May 2011

Academic Editor: Silvana I. Torri

Copyright ( $) 2011$ Ricardo de Oliveira Munhoz et al. This is an open access article distributed under the Creative Commons Attribution License, which permits unrestricted use, distribution, and reproduction in any medium, provided the original work is properly cited.

\begin{abstract}
Land application of biosolids (SS) can cause a buildup of phosphorus (P) in the top soil. The changes in the soil P characteristics may be assessed by the sorption isotherm and the sequential fractionation techniques. Samples of Haplorthox were collected from a field experiment where maize was cultivated for two years, after two applications of SS originated from two cities of São Paulo State, Brazil. SS applications added a total of 125, 250, 500, 1000 and $2000 \mathrm{~kg} \mathrm{ha}^{-1}$ of P in the area. To perform the sorption isotherms and obtain $\mathrm{P}$ maximum sorption capacity $\left(Q_{\max }\right)$ and the binding energy, soil samples were submitted to increasing $\mathrm{P}$ concentration solutions until equilibrium was reached. Sequential fractionation was done by a sequential extraction with $\mathrm{CaCl}_{2}$, $\mathrm{NaHCO}_{3}, \mathrm{NaOH}, \mathrm{HCl}$, and $\mathrm{HNO}_{3}+\mathrm{HClO}_{4}$ (residual). Addition of biosolids from both cities to the soil decreased $Q_{\max }$ and the binding energy obtained by the Langmuir equation. SS additions changed the P fractions distribution in the soil by increasing the labile fractions $\left(\mathrm{P}-\mathrm{CaCl}_{2}\right.$ and $\left.\mathrm{P}-\mathrm{NaHCO}_{3}\right)$ and the moderately labile fraction $(\mathrm{P}-\mathrm{NaOH})$ by $11.2 \%$ and $20.3 \%$, respectively, in detriment of the most resistant $\mathrm{P}$ fraction.
\end{abstract}

\section{Introduction}

A sustainable option to dispose biosolids (SS) originated from sewage treatment plants is the use as soil conditioner or as a source of nutrients to plants. Nevertheless, high SS rates might add to soil excessive amounts of phosphorus (P). One of the consequences is the increase on the risk of environment contamination by $\mathrm{P}$ transport to superficial water reservoirs, since $\mathrm{P}$ can be weakly sorbed in the superficial soil layer and carried over by rainfall runoff. Furthermore, topsoil $\mathrm{P}$ concentrations have been related to $\mathrm{P}$ movement below the plough layer and tile flow [1]. Recently, Gebrim et al. [2] observed that $\mathrm{P}$ leaching through the profile can be significant in highly weathered soils, where residual $\mathrm{P}$ is accumulated by successive crops, particularly when poultry litter is applied as fertilizer.

Among the useful parameters to monitor the increase in soil $\mathrm{P}$ availability is the $\mathrm{P}$ sorption capacity and $\mathrm{P}$ distribution among the main soil fractions. The application of organic residues to soils might implicate in change in soil $\mathrm{P}$ sorption capacity. According to Reddy et al. [3], application of organic wastes increases soluble $\mathrm{P}$ and decreases the $\mathrm{P}$ sorption capacity of the soil, and these parameters were directly related to the loading rates of animal wastes. The positive effects of manure on the solubility of $\mathrm{P}$ are due to the addition of soluble inorganic $\mathrm{P}$ and mineralization of organic $\mathrm{P}$ during decomposition of waste, which probably saturated the adsorption sites. Or else, some organic acids released during residue decomposition might compete with $\mathrm{P}$ for the same sorption sites in the soil solid phase, decreasing the element immobilization or forming stable complexes with $\mathrm{Fe}$ and $\mathrm{Al}$ and consequently blocking $\mathrm{P}$ retention by them [4]. Nevertheless, it is supposed that frequent SS addition can increase the soil organic matter content which has a positive correlation with the capacity of soil in retaining $\mathrm{P}$ [5].

The sorption isotherms can be useful to detect such alterations. This technique consists of mixing a P-enriched solution with a soil sample, at constant temperature and ionic strength, and graphically plotting the $\mathrm{P}$ quantity sorbed by soil versus the $\mathrm{P}$ remained in solution. The curve yielded, which although asymptotic, can be described by equations such as the Freundlich or Langmuir. The Langmuir equation 
can better provide estimates of $\mathrm{P}$ sorption maximum and the sorption strength of the soil, parameters inherent in determining the rate of $\mathrm{P}$ movement through the soil [6]. The Langmuir equation in its simplest form assumes only monolayer sorption and hence tends to greatly underestimate the $\mathrm{P}$ sorption maximum but yields an estimate of $\mathrm{P}$ sorption strength that represents an average of the total population of sorption sites [6]. Holford et al. [7] proposed that to measure a reasonable $\mathrm{P}$ sorption maximum, a "twosurface" Langmuir equation should be used. This equation assumes that the total number of sorption sites can be separated into two populations, one with an affinity much greater than the other. According to these authors, the application of this equation to studies of $\mathrm{P}$ sorption in soil has revealed much in terms of the relative effect of soil constituents, including $\mathrm{P}$ fertilizer and manure application rates and soil fertility.

After SS addition to the soil, the $\mathrm{P}$ species present in the material will react in different ways, depending on the soil chemical, physical, or biological characteristics, until the steady state equilibrium. This dynamics can be evaluated through the element redistribution in the main soil fractions. Therefore, the sequential fractionation is an important tool once it is based on the extractor affinity with a specific-soil $\mathrm{P}$ species. The method of Heddley et al. [8], for instance, is able to identify four main P fractions: (a) labile $\mathrm{P}$ ( $\mathrm{P}$ extractable by anionic resin plus $\mathrm{P}$ extractable by $\mathrm{NaHCO}_{3}$ ); (b) moderately labile $\mathrm{P}$ ( extractable by $\mathrm{NaOH}$ ); (c) P bound to $\mathrm{Ca}$ (extractable by $\mathrm{HCl}$ ) and (d) residual $\mathrm{P}$ (determined after nitric-perchloric acid digestion).

In Brazil, there is little information about the SS effects on soil $\mathrm{P}$ dynamics. Thus, any new available information quantifying and/or identifying some of the soil P dynamic steps will be relevant to improve the efficacy and safety of actual recommendations on SS application in agricultural lands.

The objectives of this work were to evaluate, by means of sorption isotherms, the possible changes in soil $\mathrm{P}$ sorption capacity and also to assess $P$ redistribution among the main $\mathrm{P}$ fractions in an oxisol that received two successive applications of sewage sludge.

\section{Material and Methods}

Soil samples were collected from a long-term experiment under field conditions, on an Haplorthox area (dystrophic Red Yellow Oxisol) in the experiment station of Embrapa, at Jaguariúna $\left(22^{\circ} 41^{\prime} \mathrm{S} ; 47^{\circ} 06^{\prime} \mathrm{W} \cdot \mathrm{Gr}\right.$.; altitude $\left.570 \mathrm{~m}\right)$, State of São Paulo, Brazil, after two SS additions. Some of the soil chemical and physical characteristics before SS additions are given in Table 1. Organic matter (OM) was determined by a colorimetric procedure, after digestion of samples with sodium dichromate solution in sulfuric acid and comparing the readings with a standard curve prepared with soil samples previously analyzed by Walkley-Black's method [9]. Soil $\mathrm{pH}\left(1: 2.5\right.$ solid/solution ratio) was determined in a $\mathrm{CaCl}_{2}$ $0.01 \mathrm{~mol} \mathrm{~L}^{-1}$ solution. In the same suspension, the SMP buffer $\mathrm{pH}$ was measured, and with this value, the potential
TABLE 1: Selected chemical and physical characteristics of the studied soil.

\begin{tabular}{|c|c|}
\hline Soil attribute & Value \\
\hline $\mathrm{pH}\left(\mathrm{CaCl}_{2}\right)$ & 4.4 \\
\hline Organic matter $\left(\mathrm{g} \mathrm{kg}^{-1}\right)$ & 22 \\
\hline $\mathrm{P}\left(\mathrm{mg} \mathrm{kg}^{-1}\right)$ & 9.4 \\
\hline $\mathrm{K}\left(\mathrm{mmol}_{\mathrm{c}} \mathrm{kg}^{-1}\right)$ & 1.2 \\
\hline $\mathrm{Ca}\left(\mathrm{mmol}_{\mathrm{c}} \mathrm{kg}^{-1}\right)$ & 18.9 \\
\hline $\mathrm{Mg}\left(\mathrm{mmol}_{\mathrm{c}} \mathrm{kg}^{-1}\right)$ & 11.8 \\
\hline $\mathrm{H}+\mathrm{Al}\left(\mathrm{mmol}_{\mathrm{c}} \mathrm{kg}^{-1}\right)$ & 61.4 \\
\hline $\mathrm{S}\left(\mathrm{mmol}_{\mathrm{c}} \mathrm{kg}^{-1}\right)$ & 31.9 \\
\hline $\mathrm{CEC}\left(\mathrm{mmol}_{\mathrm{c}} \mathrm{kg}^{-1}\right)$ & 93.2 \\
\hline $\mathrm{V}(\%)$ & 34 \\
\hline $\mathrm{Fe}_{\mathrm{ox}}\left(\mathrm{mmol} \mathrm{kg}^{-1}\right)$ & 18 \\
\hline $\mathrm{Al}_{\mathrm{ox}}\left(\mathrm{mmol} \mathrm{kg}{ }^{-1}\right)$ & 519 \\
\hline Coarse sand $\left(\mathrm{g} \mathrm{kg}^{-1}\right)$ & 340 \\
\hline Fine sand $\left(\mathrm{g} \mathrm{kg}^{-1}\right)$ & 240 \\
\hline Silt $\left(\mathrm{g} \mathrm{kg}^{-1}\right)$ & 100 \\
\hline Clay $\left(\mathrm{g} \mathrm{kg}^{-1}\right)$ & 320 \\
\hline Bulk density $\left(\mathrm{g} \mathrm{dm}^{-3}\right)$ & 1.18 \\
\hline
\end{tabular}

acidity was evaluated [10]. Phosphorus (P), calcium (Ca), magnesium $(\mathrm{Mg})$, and potassium $(\mathrm{K})$ were extracted from the soil by an ion-exchange resin procedure, after a 16hour shaking period. $\mathrm{P}$ was determined by colorimetric method, $\mathrm{K}$ by flame photometry, and $\mathrm{Ca}$ and $\mathrm{Mg}$ by atomic absorption spectrophotometry [11]. The values of sum of bases (S), cation exchange capacity (CEC), and percent base saturation (V) were calculated. Oxalate-extractable $\mathrm{Fe}$ and $\mathrm{Al}$ were obtained by extraction with ammonium oxalate-oxalic acid [12] to determine $\mathrm{P}$ associated with amorphous oxides of $\mathrm{Fe}$ and $\mathrm{Al}$. Physical analysis was performed according to Camargo et al. [13]. The hydrometer method was used for particle-size analysis after dispersion with a mixture of $0.015 \mathrm{~mol} \mathrm{~L}^{-1}\left(\mathrm{NaPO}_{3}\right)_{6} \cdot \mathrm{Na}_{2} \mathrm{O}$ and $0.1 \mathrm{~mol} \mathrm{~L}^{-1} \mathrm{NaOH}$ by overnight shaking. Bulk density was determined on $76 \mathrm{~mm} \times 76 \mathrm{~mm}$ diameter undisturbed soil cores [14].

The main objective was to evaluate the agroenvironmental effects caused by successive SS applications before maize (Zea mays L., CATI AL 30 cultivar) cropping. Hence, in order to evaluate the environmental impacts, such as heavymetal phytoavailability and accumulation in soil and nitrate leaching, biosolids were also applied in higher amounts than the recommended for optimal crop growth. Biosolids from the cities of Barueri and Franca, both from the State of São Paulo, were used in the experiment. Some SS characteristics are presented in Table 2. Nitrogen was determined in the original SS-samples using the Kjeldahl method (vapor distillation), and the organic- $\mathrm{C}$ was determined by titrimetry after dichromate digestion in digester block, according to Raij et al. [15]. Phosphorus, sulfur, calcium, magnesium, and potassium were analyzed according to the recommendations of US-EPA (SW-846) method no. 3051 [16] K by flame photometry, and other elements by ICP-AES. Humidity was 
TABLE 2: Partial chemical analysis of biosolids samples originated from Barueri and Franca cities and used for two crops growth.

\begin{tabular}{|c|c|c|c|c|c|}
\hline \multirow{2}{*}{ Variables } & \multirow{2}{*}{ Unity } & \multicolumn{2}{|c|}{ Barueri } & \multicolumn{2}{|c|}{ Franca } \\
\hline & & 1 st crop & 2nd crop & 1st crop & 2nd crop \\
\hline $\mathrm{pH}$ & - & 6.6 & 6.4 & 6.3 & 6.4 \\
\hline Organic carbon & $\mathrm{g} \mathrm{kg}^{-1}$ & 248 & 271 & 305 & 374 \\
\hline $\mathrm{C} / \mathrm{N}$ ratio & - & 11.8 & 10.3 & 5.4 & 7.4 \\
\hline Humidity & $\mathrm{g} \mathrm{kg}^{-1}$ & 66 & 533 & 83 & 521 \\
\hline Total nitrogen & $\mathrm{g} \mathrm{kg}^{-1}$ & 21.0 & 26.4 & 56.4 & 50.8 \\
\hline Available nitrogen & $\mathrm{g} \mathrm{kg}^{-1}$ & 5.7 & 22.5 & 15.3 & 25.7 \\
\hline Total phosphorus & $\mathrm{g} \mathrm{kg}^{-1}$ & 16 & 31.2 & 16 & 21.3 \\
\hline Total sulfur & $\mathrm{g} \mathrm{kg}^{-1}$ & 13.4 & 10.8 & 16.3 & 13.3 \\
\hline Total calcium & $\mathrm{g} \mathrm{kg}^{-1}$ & 40.3 & 22.8 & 29.2 & 16.8 \\
\hline Total magnesium & $\mathrm{g} \mathrm{kg}^{-1}$ & 3.0 & 3.7 & 2.2 & 2.5 \\
\hline Total potassium & $\mathrm{g} \mathrm{kg}^{-1}$ & 1.0 & 2.0 & 1.0 & 1.0 \\
\hline
\end{tabular}

determined by mass loss at $60^{\circ} \mathrm{C}$ and SS sample $\mathrm{pH}$ was determined in water extract $(1: 5)$.

The experiment consisted of twelve treatments in a randomized complete block design with three replications, in a total of 36 plots, each plot measuring $20 \mathrm{~m}$ length versus $10 \mathrm{~m}$ width. The study treatments were: two control (no N, $\mathrm{P}$ and $\mathrm{K}$ applied); two mineral fertilization recommended for the crop ( $46 \mathrm{~kg} \mathrm{~N} \mathrm{ha}^{-1}$ for the first crop and $90 \mathrm{~kg} \mathrm{~N} \mathrm{ha}^{-1}$ for the second crop; $37 \mathrm{~kg} \mathrm{Pha}^{-1}$ and $56 \mathrm{~kg} \mathrm{Kha}^{-1}$ on both crops) [17]; four treatments with the SS from the city of Franca, four treatments with the SS from the city of Barueri. The sewage sludge treatments were applied based on the $\mathrm{N}$ concentration that provides the same amount of $\mathrm{N}$ as in the mineral fertilization recommended for corn; two, four, and eight times the $\mathrm{N}$ recommended dosage for corn crop. Calculations of sludge rates were performed as a function of the $\mathrm{N}$ available for plants and were calculated by the formula

$$
\begin{aligned}
\text { SS available } \mathrm{N}= & \left(\frac{\mathrm{MF}}{100}\right) \times\left(\text { Kjeldahl-N-NH} \mathrm{N}_{3}-\mathrm{N}\right) \\
& +\mathrm{NH}_{3}-\mathrm{N}+\left(\mathrm{NO}_{3}{ }^{-}-\mathrm{N}+\mathrm{NO}_{2}{ }^{-}-\mathrm{N}\right),
\end{aligned}
$$

where Kjeldahl-N: total nitrogen $\left(\mathrm{mg} \mathrm{kg}^{-1}\right), \mathrm{NH}_{3}-\mathrm{N}$ : nitrogen as ammonia $\left(\mathrm{mg} \mathrm{kg}^{-1}\right), \mathrm{NO}_{3}^{-}-\mathrm{N}$ : nitrogen as nitrate $\left(\mathrm{mg} \mathrm{kg}{ }^{-1}\right), \mathrm{NO}_{2}{ }^{-}-\mathrm{N}$ : nitrogen as nitrite $\left(\mathrm{mg} \mathrm{kg}^{-1}\right)$, and MF: mineralization fraction (30\%), for aerobically digested sludge.

Supplementary K was applied for treatments with sewage sludge, when necessary. The wet sludge was incorporated on April 1999 and on December 1999. It was toss-distributed in the total area of the experimental plots and incorporated to a depth of $20 \mathrm{~cm}$ with a rotary harrow, 3-4 days before sowing.

The P quantity in each SS rate was calculated based on the SS total P content added after two SS applications. Treatments applied were: FC = control without SS (for the plots with SS from Franca); BC = control without SS (for the plots with SS from Barueri); FP1, FP2, FP4, FP8 $=125,250$, 500 , and $1000 \mathrm{~kg} \mathrm{ha}^{-1}$ of P from Franca-SS applications; BP2, $\mathrm{BP} 4, \mathrm{BP} 8$, and BP16 $=250,500,1000$, and $2000 \mathrm{~kg} \mathrm{ha}^{-1}$ of $\mathrm{P}$ from Barueri-SS applications; FNPK and BNPK = mineral fertilized plots.
Soil samples were collected at $0-20 \mathrm{~cm}$ depth, after the second maize harvesting, air dried and passed through $2 \mathrm{~mm}$ sieve. For the $\mathrm{P}$ sorption essay, $3 \mathrm{~g}$ of soil samples of each SS- treated plot with 0, 125 (FP1), 250 (BP2), 500 (FP4), 1000 (FP8), and 2000 (BP16) $\mathrm{kg} \mathrm{ha}^{-1}$ of P were equilibrated in a $50 \mathrm{~mL}$ centrifuge tubes with $30 \mathrm{~mL}$ of $0.01 \mathrm{~mol} \mathrm{~L}^{-1}$ $\mathrm{CaCl}_{2}$ solution containing $0,5,10,15,30,60,100$ and $250 \mathrm{mg} \mathrm{L}^{-1}$ of P. Two drops of toluene were added to preserve solution from microorganism contamination. During six days, solutions were shaken for $30 \mathrm{~min}$ thrice a day. Finally, the tubes were centrifuged at $577 \times \mathrm{g}$ for $15 \mathrm{~min}$ to separate supernatant from the solid material, and $\mathrm{P}$ was determined in the suspension [18]. The difference between the $\mathrm{P}$ in the equilibrium solution and $\mathrm{P}$ added is the quantity of $\mathrm{P}$ adsorbed by the soil. The adsorption isotherms, which represent the linear fit of the relationship between adsorbed $\mathrm{P}$ and the equilibrium solution $\mathrm{P}$, were built with the results obtained with all P concentrations. Sorption strengths were calculated with the simple (monolayer) Langmuir equation, which gives an average sorption strength of the P sorbed [6],

$$
Q=k Q_{\max } \frac{C}{(1+k C)},
$$

where $Q$ is the $P$ sorbed $\left(\mathrm{mg} \mathrm{kg}^{-1}\right), k$ is the sorption strength $\left(\mathrm{L} \mathrm{mg}^{-1} \mathrm{P}\right), Q_{\max }$ is the maximum quantity of $\mathrm{P}$ sorbed for monolayer $\mathrm{P}$ sorption $\left(\mathrm{mg} \mathrm{kg}^{-1}\right)$, and $C$ is the concentration of $\mathrm{P}$ in solution $\left(\mathrm{mg} \mathrm{L}^{-1}\right)$.

The total P sorption maximum $\left(Q_{\max }: \mathrm{mg} \mathrm{kg}^{-1}\right)$ was calculated as the sum of $\mathrm{P}$ sorption maxima $\left(Q_{\max 1}\right.$ and $\left.Q_{\max 2}\right)$ derived from the two-surface Langmuir equation [19]. For the two-surface Langmuir equation,

$$
Q=\left(k_{1} Q_{\max 1} \frac{C}{\left[1+k_{1} C\right]}\right)+\left(k_{2} Q_{\max 2} \frac{C}{\left[1+k_{2} C\right]}\right)
$$

where $\mathrm{Q}$ is the $\mathrm{P}$ sorbed $\left(\mathrm{mg} \mathrm{kg}^{-1}\right), k_{1}$ and $k_{2}$ are the sorption strengths of the first and the second sorption layers $\left(\mathrm{L} \mathrm{mg}^{-1} \mathrm{P}\right), Q_{\max 1}$ and $Q_{\max 2}$ are the maximum quantities of $\mathrm{P}$ sorbed for two sorption layers $\left(\mathrm{mg} \mathrm{kg}^{-1}\right)$, and $C$ is the concentration of $\mathrm{P}$ in solution $\left(\mathrm{mg} \mathrm{L}^{-1}\right)$. 
The sequential fractionation was based on the method of Heddley et al. [8], modified by Sui [20], and also with the following modifications: $0.01 \mathrm{~mol} \mathrm{~L}^{-1} \mathrm{CaCl}_{2}$ solution instead of $\mathrm{H}_{2} \mathrm{O}$, centrifugation at $1073 \times \mathrm{g}$ at $5^{\circ} \mathrm{C}$, and filtering through Whatman 41 paper $(20-25 \mu \mathrm{m})$ instead of $0.22 \mu \mathrm{m}$. Samples were selected only from Barueri SS treatments that added 0, 250 (BP2), 1000 (BP8), and 2000 (BP16) $\mathrm{kg} \mathrm{Pha}^{-1}$. An aliquot of $0.5 \mathrm{~g}$ of each sample was submitted to nitric-perchloric digestion to determine the total $\mathrm{P}(\mathrm{Pt})$ concentration by Inductively Coupled Plasma Atomic Emission Spectroscopy (ICP-AES). Another equal aliquot sample was transferred to $50 \mathrm{~mL}$ centrifuge tubes and submitted to $\mathrm{P}$ extraction using a sequence of $\mathrm{P}$ extracting solutions: $30 \mathrm{~mL}$ of $0.01 \mathrm{~mol} \mathrm{~L}^{-1} \mathrm{CaCl}_{2}$ solution; $30 \mathrm{~mL}$ of $0.5 \mathrm{~mol} \mathrm{~L}^{-1}$ $\mathrm{NaHCO}_{3}(\mathrm{pH} 8.2) ; 30 \mathrm{~mL} 0.1 \mathrm{~mol} \mathrm{~L}^{-1} \mathrm{NaOH} ; 30 \mathrm{~mL}$ of $1.0 \mathrm{~mol} \mathrm{~L}^{-1} \mathrm{HCl}$. Each soil-solution mixture was shaken for 16 hours, centrifuged at 3,000 g for 15 minutes, and filtered through Whatman 41 filter paper. The inorganic phosphorus (Pi) was determined by colorimetric method described by Murphy and Riley [18], and the organic phosphorus (Po) was determined by the difference between $\mathrm{Pt}$ and $\mathrm{Pi}$ in the same extract. After the last extracting solution, the soil residue remained in each centrifuge tube was submitted to nitricperchloric digestion, and $\mathrm{P}$ content was determined by ICPAES.

This procedure of sequential fractionation allowed identifying four types of $\mathrm{P}$ bindings to the solid phase: (a) labile or biologically available $\mathrm{P}$, extracted by $\mathrm{CaCl}_{2}$ solution and by $\mathrm{NaHCO}_{3}$ solution; (b) chemisorbed or moderately labile $\mathrm{Pi}$ and $\mathrm{Po}$ (bound to $\mathrm{Fe}$ and $\mathrm{Al}$ oxides) extracted by $\mathrm{NaOH}$ solution; (c) P (bound to $\mathrm{Ca}$ ) extracted by $\mathrm{HCl}$ solution; (d) residual $\mathrm{P}$.

Langmuir monolayer equations were evaluated on the basis of statistical significance of the regression coefficients.

\section{Results and Discussion}

Sewage sludge addition from both cities (Franca and Barueri) decreased soil $\mathrm{P}$ sorption capacity in all rates under investigation (Figures 1(a) and 1(b)). Such behavior was expected since SS usually contains water soluble P [21], and the SS tested here presented more than $0.3 \%$ total $\mathrm{P}$ [22] and a $\mathrm{C}: \mathrm{P}$ ratio less than 100 [23] which also favors the decrease in $\mathrm{P}$ sorption by releasing more $\mathrm{P}$ into soil solution as a result of organic P mineralization. Berton and Pratt [21] also used the isotherms to evaluate the effects of increasing rates of four different organic materials (including SS) on the $\mathrm{P}$ adsorption capacity of two soils and concluded that SS decreased $\mathrm{P}$ adsorption more effectively compared to the other materials.

The linear form of Langmuir regression equations presented a significant $R^{2}(P<0.01)$ for all SS rates applied indicating that the sorption phenomena was adequately described by this isotherm (Table 3). P sorption maxima $\left(Q_{\max }\right)$ ranged from 1130 to $1008 \mathrm{mg} \mathrm{kg}^{-1}$ and the binding energy also varied from 0.148 to $0.072 \mathrm{~L} \mathrm{mg}^{-1}$ for control and treatment $2000 \mathrm{~kg} \mathrm{ha}^{-1}$, respectively (Table 3). Both $Q_{\max }$ and the binding energy values decreased as a result of soil
SS incorporation, but this effect was linear only for the residue derived from Barueri. Although soil $Q_{\max }$ usually presents a positive correlation with soil organic matter content [5], the addition of organic residues to soil, such as manures, causes an inverse effect by decreasing $\mathrm{P}$ sorption with increase in P availability to plants [24]. Mechanisms for the reduction of sorption maxima and the affinity constants by organic amendments include the competition of organic acids produced during mineralization for the same sites of $\mathrm{P}$ fixation and the complexing of exchangeable $\mathrm{Al}$ by organic acids $[4,25,26]$. Furthermore, both sewage sludges contain inorganic ligands such as $\mathrm{SO}_{4}{ }^{2-}$ which can complex exchangeable $\mathrm{Al}$ and metals such as $\mathrm{Ca}$ and $\mathrm{Mg}$ which may form soluble complexes with $\mathrm{P}$ in the soil solution, thus preventing $\mathrm{P}$ from being fixed by $\mathrm{Al}$ or $\mathrm{Fe}$ [27].

Only the treatment with the highest P input $(2000 \mathrm{~kg}$ $\mathrm{ha}^{-1}$ ) reached the threshold value of $0.07 \mathrm{~L} \mathrm{mg}^{-1}$ proposed by $\mathrm{McDowell}$ et al. [1], whereby soils less than this value for binding strength are subject to enhance loss of $\mathrm{P}$ in subsurface flow. Since the recommended SS rate is eight times less than the highest rate tested $\left(125 \mathrm{~kg} \mathrm{ha}^{-1}\right.$ and $250 \mathrm{~kg} \mathrm{ha}^{-1}$ for Franca and Barueri cities, resp.), it indicates that the amount of SS recommended as $N$ source for corn crop may be considered safe for potential P losses in subsurface flow, but it should be monitored after successive SS applications.

The amount of $\mathrm{P}\left(\mathrm{mg} \mathrm{kg}^{-1}\right)$ in equilibrium with $0.2 \mathrm{mg}$ $\mathrm{PL}^{-1}\left(\mathrm{P}_{0.2}\right)$ calculated from each isotherm equation (Table 3 ) ranged from 32,49 to $14,31 \mathrm{mg} \mathrm{kg}^{-1}$ for control and treatment $2000 \mathrm{~kg} \mathrm{ha}^{-1}$, respectively. The amount of $\mathrm{P}$ sorbed at $\mathrm{P}_{0.2}$ in the equilibrium solution was decreased by increasing rates of SS from both cities and markedly reduced by the highest rates of these amendments. Sewage sludge from Franca required the double amount of added $\mathrm{P}$ to attain $\mathrm{P}_{0.2}$ in equilibrium solution compared to the sludge from Barueri ( 500 to $250 \mathrm{~kg} \mathrm{ha}^{-1}$ ), suggesting that the latter was more efficient in maintaining $\mathrm{P}$ in soil solution.

The SS from Barueri city applied to soil changed the $\mathrm{P}$ distribution within the studied $\mathrm{P}$ fractions (Table 4). Phosphorus extracted by $\mathrm{CaCl}_{2}$ was markedly increased only at $\mathrm{P}$ rate of $2000 \mathrm{~kg} \mathrm{ha}^{-1}$. The $\mathrm{P}$ rates applied as SS had little effect over $\mathrm{P}_{0}-\mathrm{NaHCO}_{3}$. In relative values, this $\mathrm{P}$ fraction decreased from 10.8 to $4.9 \%$ as long as $\mathrm{P}$ rates increased from $250 \mathrm{~kg} \mathrm{ha}^{-1}$ to $2000 \mathrm{~kg} \mathrm{ha}^{-1}$ (Table 5). This apparent little variation of $\mathrm{P}_{o}-\mathrm{NaHCO}_{3}$ fraction might probably be attributed to an intense organic $\mathrm{P}$ mineralization which could have contributed to increase $\mathrm{Pi}-\mathrm{NaHCO}_{3}$ fraction from 9.1\% (control plot) to $18.1 \%$ (highest $\mathrm{P}$ rate-2000 $\mathrm{kg} \mathrm{ha}^{-1}$ ). Similar results were found by Sui et al. [20] who suggested that $\mathrm{P}_{o}-\mathrm{NaHCO}_{3}$ fraction might be responsible for an extra increase in $\mathrm{Pi}-\mathrm{NaHCO}_{3}$ fraction. Nevertheless, the $\mathrm{P}_{o}$ from the $\mathrm{P}_{o}-\mathrm{NaHCO}_{3}$ fraction might also be adsorbed to $\mathrm{Al}$ and $\mathrm{Fe}$ oxides, favoring the increasing $\mathrm{P}_{\mathrm{o}}-\mathrm{NaOH}$ fraction from $1.5 \%$ to $11.3 \%$ (Table 5 ).

Compared with any other $\mathrm{P}$ fractions, the contribution of $\mathrm{P}$ added as $\mathrm{SS}$ to the $\mathrm{NaOH}$ fraction was most evident and illustrates the $\mathrm{P}$ affinity to $\mathrm{Fe}$ and $\mathrm{Al}$ oxides, a relationship that predominates in oxisols. The increases of chemisorbed $\mathrm{P}$ observed on all SS treatments were likely the result of soluble inorganic $\mathrm{P}$ added with the organic residue and $\mathrm{P}$ 


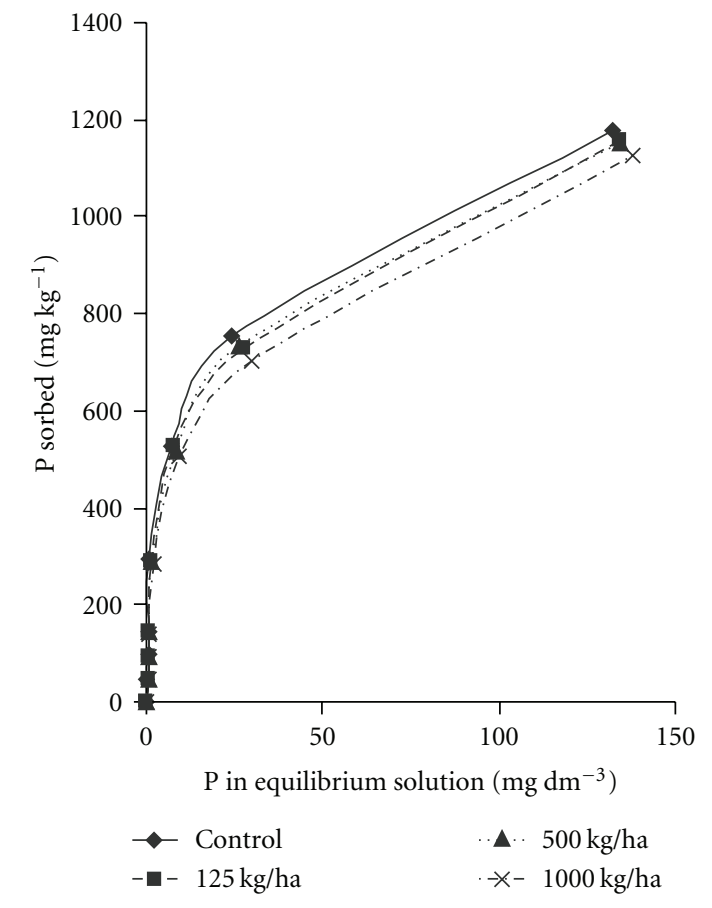

(a)

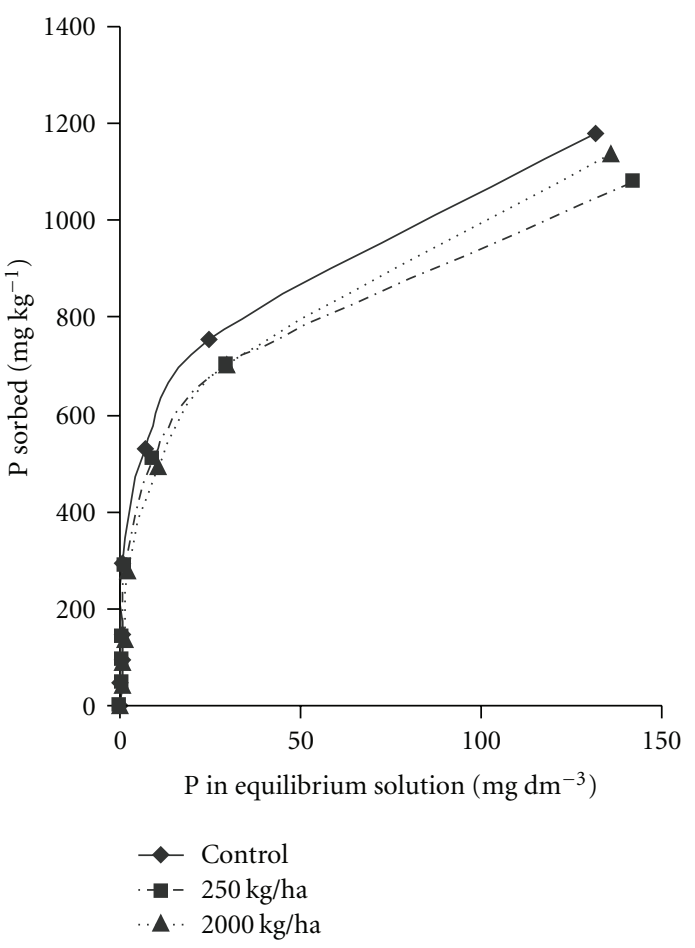

(b)

FIgURE 1: Phosphorus sorption in a Haplorthox treated with increasing amounts of P applied through biosolids addition from cities of Franca (a) and Barueri (b).

TABLE 3: Linear Langmuir equations and parameters in the soil samples which received phosphorus addition as biosolids.

\begin{tabular}{|c|c|c|c|c|c|}
\hline Phosphorus inputs & Regression Equations $^{(1)}$ & $\mathrm{R}^{2}$ & $Q_{\max }^{(2)}$ & Binding energy & $\mathrm{P}_{0.2}{ }^{(3)}$ \\
\hline $\mathrm{kgha}^{-1}$ & & & $\mathrm{mg} \mathrm{kg}^{-1}$ & $\mathrm{~L}^{-1} \mathrm{mg}$ & $\mathrm{mg} \mathrm{kg}^{-1}$ \\
\hline \multirow[t]{2}{*}{0} & $\mathrm{Y}=5.51+0.82 \mathrm{X}$ & $0.99^{* *}$ & 1130 & 0.148 & 32,5 \\
\hline & SS from Franca & & & & \\
\hline 125 & $Y=7.08+0.82 X$ & $0.99 * *$ & 1074 & 0.116 & 24.4 \\
\hline 500 & $\mathrm{Y}=7,79+0.82 \mathrm{X}$ & $0.99^{* *}$ & 1086 & 0.105 & 22.3 \\
\hline \multirow[t]{2}{*}{1000} & $\mathrm{Y}=9.91+0.83 \mathrm{X}$ & $0.99 * *$ & 1050 & 0.084 & 17.4 \\
\hline & SS from Barueri & & & & \\
\hline 250 & $\mathrm{Y}=8.21+0.88 \mathrm{X}$ & $0.99^{* *}$ & 1082 & 0.107 & 22.7 \\
\hline 2000 & $\mathrm{Y}=11.22+0.81 \mathrm{X}$ & $0.99^{* *}$ & 1008 & 0.072 & 14.3 \\
\hline
\end{tabular}

TABLE 4: Phosphorus fractions in a soil treated with increasing rates of biosolids.

\begin{tabular}{|c|c|c|c|c|c|c|c|c|c|c|c|}
\hline \multirow[t]{2}{*}{ Phosphorus rate } & \multirow[t]{2}{*}{$\mathrm{CaCl}_{2}$} & \multicolumn{3}{|c|}{$\mathrm{NaHCO}_{3}$} & \multicolumn{3}{|c|}{$\mathrm{NaOH}$} & \multirow[t]{2}{*}{$\mathrm{HCl}$} & \multirow[t]{2}{*}{ Residual } & \multirow[t]{2}{*}{ Total (sum) } & \multirow[t]{2}{*}{ Total } \\
\hline & & $\mathrm{P}_{o}$ & $\mathrm{P}_{i}$ & $\mathrm{P}_{t}$ & $\mathrm{P}_{o}$ & $\mathrm{P}_{i}$ & $\mathrm{P}_{t}$ & & & & \\
\hline $\mathrm{kg} \mathrm{ha}^{-1}$ & \multicolumn{11}{|c|}{$\mathrm{mg} \mathrm{kg}^{-1}$} \\
\hline 0 & 5 & 11 & 36 & 47 & $6 f$ & 32 & 38 & 15 & 289 & 394 & 343 \\
\hline 250 & 6 & 51 & 47 & 98 & 14 & 54 & 68 & 36 & 260 & 468 & 367 \\
\hline 1000 & 8 & 41 & 80 & 121 & 32 & 103 & 135 & 33 & 322 & 618 & 507 \\
\hline 2000 & 14 & 44 & 165 & 209 & 103 & 170 & 273 & 39 & 378 & 913 & 787 \\
\hline
\end{tabular}

$\mathrm{P}_{i}$ : inorganic phosphorus; $\mathrm{P}_{o}$ : organic phosphorus; $\mathrm{P}_{t}$ : total phosphorus. 
TABLE 5: Average proportions of $\mathrm{P}$ fractions in soil samples amended with increasing amounts of biosolids.

\begin{tabular}{|c|c|c|c|c|c|c|c|}
\hline \multirow[t]{2}{*}{ P rate } & \multirow[t]{2}{*}{$\mathrm{CaCl}_{2}$} & \multicolumn{2}{|c|}{$\mathrm{NaHCO}_{3}$} & \multicolumn{2}{|c|}{$\mathrm{NaOH}$} & \multirow[t]{2}{*}{$\mathrm{HCl}$} & \multirow[t]{2}{*}{ Residual } \\
\hline & & $\mathrm{P}_{o}$ & $\mathrm{P}_{i}$ & $\mathrm{P}_{o}$ & $\mathrm{P}_{i}$ & & \\
\hline $\mathrm{kgha}^{-1}$ & & & & $\%$ & & & \\
\hline 0 & 1.3 & 2.8 & 9.1 & 1.5 & 8.1 & 3.8 & 73.4 \\
\hline 250 & 1.3 & 10.9 & 10.0 & 3.0 & 11.5 & 7.7 & 55.6 \\
\hline 1000 & 1.3 & 6.6 & 12.9 & 5.2 & 16.7 & 5.3 & 52.1 \\
\hline 2000 & 1.5 & 4.8 & 18.1 & 11.3 & 18.6 & 4.3 & 41.4 \\
\hline
\end{tabular}

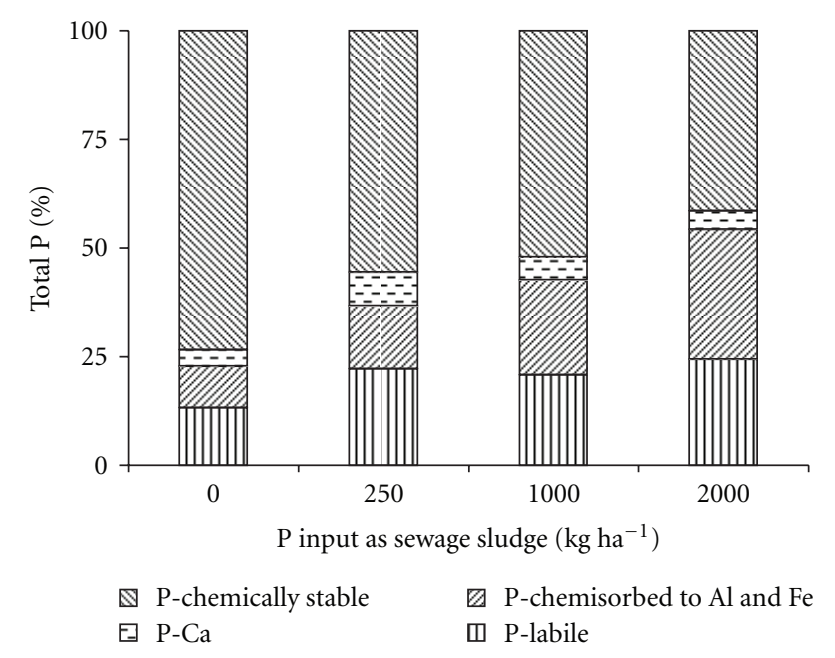

FIGURE 2: Percent distribution of P fractions in soil samples amended with increasing amounts of biosolids from Barueri city.

mineralized from added organic $\mathrm{P}$ [28]. Since the $\mathrm{NaOH}$ extractant removes a $\mathrm{P}$ fraction which is associated with amorphous and crystalline $\mathrm{Al}$ and Fe phosphates $[29,30]$, the addition of SS appears to have a significant impact on soil $\mathrm{P}$ sorption, as showed by the sorption isotherms (Figure 1(b)).

Addition of SS increased $\mathrm{P}-\mathrm{HCl}$ fraction, but it was not proportional to the rates of SS applied. Novais and Smyth [31] suggested that the low variation of $\mathrm{P}-\mathrm{HCl}$ fraction with the increasing $\mathrm{P}$ rates applied to soil evidenced that $\mathrm{P}$ bound to $\mathrm{Ca}$ did not have any important role in $\mathrm{P}$ dynamics of more weathered acid soils and not treated with natural phosphates as $\mathrm{P}$ source. In these soils, the poor calcium phosphate content was probably the main factor determining the $\mathrm{HCl}$ extractable P quantity. In a similar way, Rheinheimer [32] observed in two oxisols that $\mathrm{P}$ extracted with $1.0 \mathrm{~mol} \mathrm{~L}^{-1}$ $\mathrm{HCl}$ (after resin, $0.5 \mathrm{~mol} \mathrm{~L}^{-1} \mathrm{NaHCO}_{3}$ and $0.1 \mathrm{~mol} \mathrm{~L}^{-1} \mathrm{NaOH}$ extractions) did not change with the successive extractions.

The effect of SS on soil P species distribution, increasing the element availability, can be observed by the variation occurred in three P fractions: (a) the labile fraction represented by $\mathrm{P}-\mathrm{CaCl}_{2}$ plus $\mathrm{P}-\mathrm{NaHCO}_{3}$ increased from $13.2 \%$ (control) to $24.4 \%$ of total $\mathrm{P}$; (b) the chemisorbed $\mathrm{P}$ or moderately labile fraction suggested by Bowman and Cole [30], represented by $\mathrm{P}$ forms extracted by $0.1 \mathrm{~mol} \mathrm{~L}^{-1} \mathrm{NaOH}$ increased from $9.6 \%$ (control) to $29.9 \%$ of total P; consequently, (c) the most resistant residual $\mathrm{P}$ fraction decreased from $73.4 \%$ (control) to $41.4 \%$ (Figure 2 ). The redistribution of residual $\mathrm{P}$ to more labile forms was also observed by Barcellos [33] on an eutroferric red latosol amended with successive applications of SS.

\section{Conclusions}

(1) The biosolids application to soil decreased soil P sorption which resulted in an increase of $\mathrm{P}$ in equilibrium solution.

(2) The positive correlation of $\mathrm{P}$ extracted by $\mathrm{NaOH}$ with total $\mathrm{P}$ added as SS suggested that the decrease in soil $\mathrm{P}$ sorption can be mainly attributed to the $\mathrm{P}$ chemisorbed to amorphous and crystalline $\mathrm{Al}$ and $\mathrm{Fe}$.

(3) The addition of biosolids changed the P fractions distribution in the soil, favoring $\mathrm{P}$ availability to plants and its geoavailability by increasing the labile fractions $\left(\mathrm{P}-\mathrm{CaCl}_{2}\right.$ and $\left.\mathrm{P}-\mathrm{NaHCO}_{3}\right)$ and the moderately labile fraction $(\mathrm{P}-\mathrm{NaOH})$ by $11.2 \%$ and $20.3 \%$, respectively, in detriment of the most resistant $\mathrm{P}$ fraction.

\section{References}

[1] R. McDowell, A. Sharpley, and P. Withers, "Indicator to predict the movement of phosphorus from soil to subsurface flow," Environmental Science and Technology, vol. 36, no. 7, pp. 1505-1509, 2002.

[2] F. O. Gebrim, R. F. Novais, I. R. Silva et al., "Mobility of inorganic and organic phosphorus forms under different levels of phosphate and poultry litter fertilization in soils," Revista Brasileira de Ciência do Solo, vol. 34, no. 4, pp. 1195-1205, 2010.

[3] K. R. Reddy, M. R. Overcash, R. Khaleel, and P. W. Westerman, "Phosphorus adsorption-desorption characteristics of two soils utilized for disposal of animal wastes," Journal of Environmental Quality, vol. 9, no. 1, pp. 86-92, 1980.

[4] S. Nagarajah, A. M. Posner, and J. P. Quirk, "Competitive adsorption of phosphate with polygalacturonate and other organic anions on kaolinite and oxide surfaces," Nature, vol. 228, no. 5266, pp. 83-85, 1970.

[5] S. K. Sanyal and S. K. De Datta, "Chemistry of phosphorus transformations in soil," Advances in Soil Sciences, vol. 16, pp. 1-120, 1991.

[6] I. C. R. Holford, C. Hird, and R. Lawrie, "Effects of animal effluents on the phosphorus sorption characteristics of soils," The Australian Journal of Soil Research, vol. 35, no. 2, pp. 365373, 1997.

[7] I. C. R. Holford, R. W. M. Wedderburn, and G. E. G. Mattingly, "A Langmnuir two-surface equation as a model of phosphate 
adsorption by soils," Journal of Soil Science, vol. 25, pp. 242254, 1974.

[8] M. J. Heddley, J. W. B. Stewart, and B. S. Chauhuan, "Changes in organic and organic soil phosphorus fractions induced by cultivation practices and laboratory incubations," Soil Science Society of America Journal, vol. 46, pp. 970-976, 1982.

[9] A. Walkley and I. A. Black, "An examination of the Degtjareff method for determining organic carbon in soils: effect of variations in digestion conditions and of inorganic soil constituents," Soil Science, vol. 63, pp. 251-263, 1934.

[10] H. E. Shoemaker, E. O. McLean, and P. F. Pratt, "Buffer methods for determining lime requirement of soils with appreciable amounts of extractable aluminum," Soil Science Society of America Proceedings, vol. 25, pp. 274-277, 1961.

[11] B. van Raij, J. A. Quaggio, and N. M. Silva, "Extraction of phosphorus, potassium, calcium and magnesium from soils by an ion-exchange resin procedure," Communications in Soil Science and Plant Analysis, vol. 14, no. 5, pp. 547-566, 1986.

[12] L. J. Evans and W. G. Wilson, "Extractable Fe, Al, Si and C in Bhorizons of podzolic and brunisolic soils from Ontario," The Canadian Journal of Soil Science, vol. 65, no. 3, pp. 489-496, 1985.

[13] O. A. Camargo, A. C. Moniz, T. A. Jorge, and J. M. A. S. Valadares, Métodos de Análise Química, Mineralógica e Física de Solos do Instituto Agronômico de Campinas, Instituto Agronômico, Campinas, Brazil, 1986.

[14] R. E. Uhland, "Physical properties of soils as modified by crops and management," Soil Science Society of America Proceedings, vol. 14, pp. 361-366, 1950.

[15] B. van Raij, J. A. Quaggio, H. Cantarella, and C. A. Abreu, "Os métodos de análise química do sistema I.A.C. de análise de solo no contexto nacional," in Análise Química para Avaliação da Fertilidade de Solos Tropicais, B. van Raij, J. C. Andrade, H. Cantarella, and J. A. Quaggio, Eds., pp. 5-39, Instituto Agronômico, Campinas, Brazil, 2001.

[16] US-EPA, Test Methods for Evaluating Solid Waste: Physical/ Chemical Methods, U. S. Environmental Protection Agency/ Office of Solid Waste and Emergency Response/U. S. Government Printing Office, Washington, DC, USA, 3rd edition, 1983, (SW-846, Method 3051).

[17] B. van Raij, H. Cantarella, J. A. Quaggio, and A. M. C. Furlani, Recomendações de Adubação e Calagem para o Estado de São Paulo, Instituto Agronômico/ Fundação IAC, Campinas, Brazil, 2nd edition, 1997.

[18] J. Murphy and J. P. Riley, "A modified single solution method for the determination of phosphate in natural waters," Analytica Chimica Acta, vol. 27, pp. 125-151, 1962.

[19] I. C. R. Holford and G. E. G. Mattingley, "The high- and low-energy phosphate adsorbing surfaces in calcareous soils," Journal of Soil Science, vol. 26, pp. 407-417, 1975.

[20] Y. Sui, M. L. Thompson, and C. Shang, "Fractionation of phosphorus in a Mollisol amended with biosolids," Soil Science Society of America Journal, vol. 63, no. 5, pp. 1174-1180, 1999.

[21] R. S. Berton and P. F. Pratt, "Evaluation of phosphorus requirement by the sorption isotherm technique in soils amended with organic materials," Revista Brasileira de Ciência do Solo, vol. 21, no. 2, pp. 199-206, 1997.

[22] B. B. Singh and J. P. Jones, "Phosphorus sorption and desorption characteristics of soil as affected by organic residues," Soil Science Society of America Proceedings, vol. 40, pp. 389-395, 1976.

[23] F. Iyamuremye and R. P. Dick, "Organic amendments and phosphorus sorption by soils," Advances in Agronomy, vol. 56, pp. 139-185, 1996.
[24] C. A. M. Laboski and J. A. Lamb, "Impact of manure application on soil phosphorus sorption characteristics and subsequent water quality implications," Soil Science, vol. 169, no. 6, pp. 440-448, 2004.

[25] N. V. Hue, "Correcting soil acidity of a highly weathered ultisol with chicken manure and sewage sludge," Communications in Soil Science and Plant Analysis, vol. 23, no. 3-4, pp. 241-264, 1992.

[26] A. H. Bumaya and D. V. Naylor, "Phosphorus sorption and extractability in Andic soil incubated with plant residues of variable P content," Plant and Soil, vol. 112, no. 1, pp. 77-81, 1988.

[27] F. Iyamuremye, R. P. Dick, and J. Baham, "Organic amendments and phosphorus dynamics: I. Phosphorus chemistry and sorption," Soil Science, vol. 161, no. 7, pp. 426-435, 1996.

[28] F. Iyamuremye, R. P. Dick, and J. Baham, "Organic amendments and phosphorus dynamics: II. Distribution of soil phosphorus fractions," Soil Science, vol. 161, no. 7, pp. 436443, 1996.

[29] J. R. McLaughlin, J. C. Ryden, and J. K. Syers, “Development and evaluation of a kinetic model to describe phosphate sorption by hydrous ferric oxide gel," Geoderma, vol. 18, no. 4, pp. 295-307, 1977.

[30] R. A. Bowman and C. V. Cole, "An exploratory method for fractionation of organic phosphorus from grassland soil," Soil Science, vol. 125, pp. 95-101, 1978.

[31] R. F. Novais and T. J. Smyth, Fósforo em Solo e Planta em Condições Tropicais, Universidade Federal de Viçosa, Viçosa, Brazil, 1999.

[32] D. S. Rheinheimer, I. Anghinoni, and J. Kaminski, "Depleção do fósforo inorgânico de diferentes frações provocada pela extração sucessiva com resina em diferentes solos e manejos," Revista Brasileira de Ciência do Solo, vol. 24, pp. 345-354, 2000.

[33] I. F. Barcellos, Partição de fósforo $(P)$ em sedimento de solo tratado com lodo de esgoto e cultivado com milho, M.S. thesis, IAC, Campinas, Brazil, 2006. 

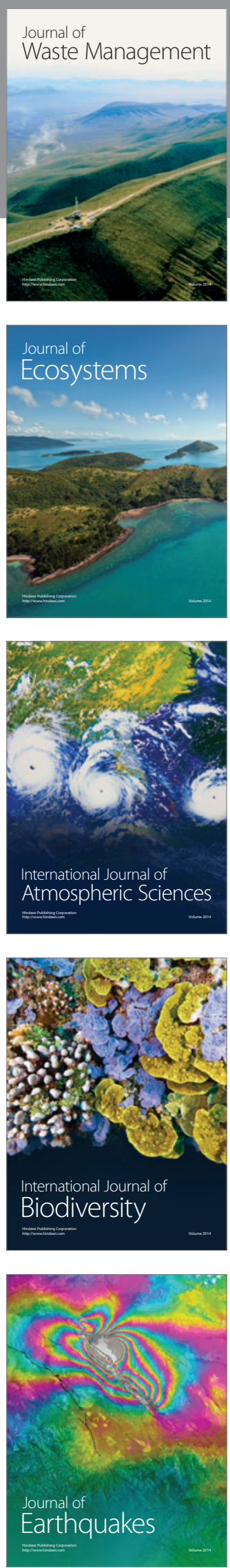
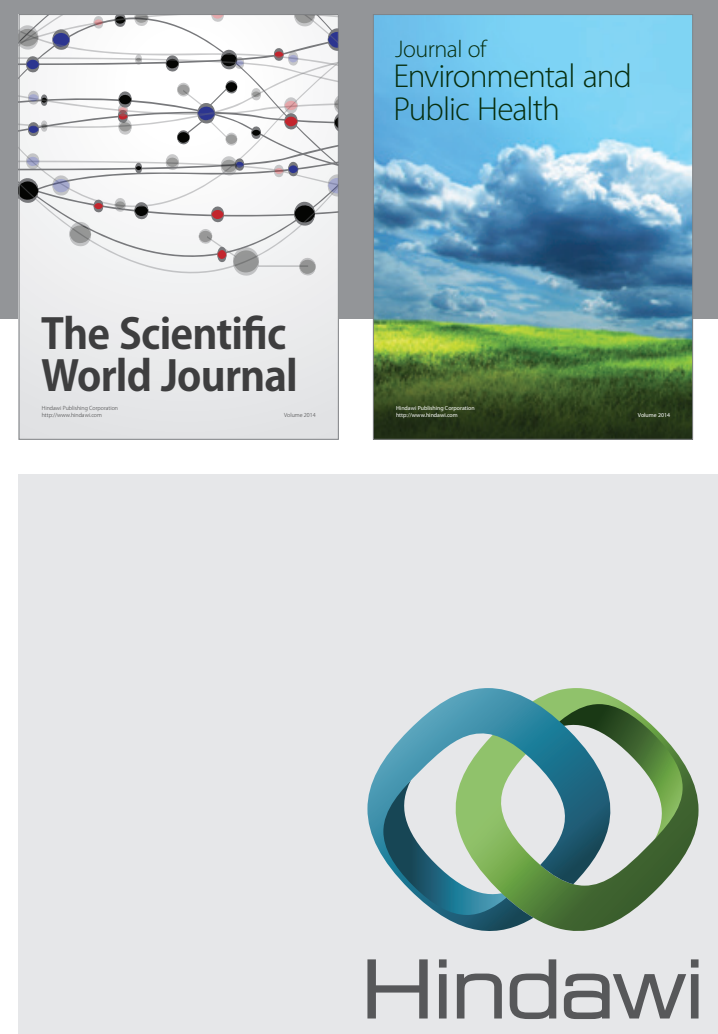

Submit your manuscripts at

http://www.hindawi.com
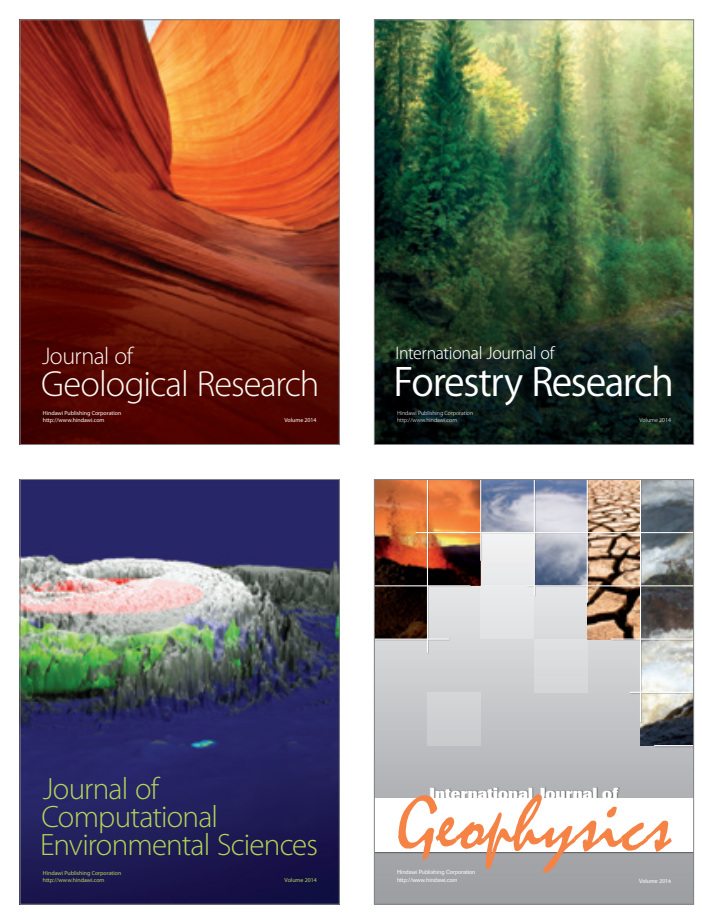
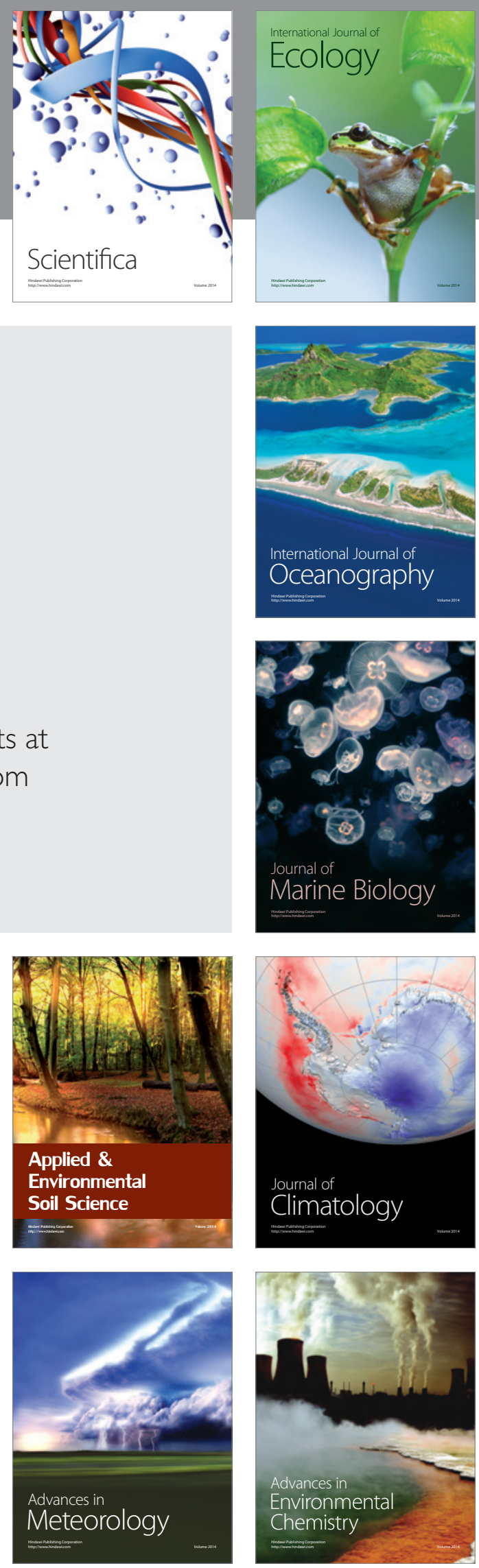